\title{
Innovation as Intervening Variable between Entrepreneurial Orientation and Learning Orientation with Company Performance on MSEs in Ambon City
}

\author{
Zany Irayati Aunalal \\ Lecturer, Department of Business Administration, State Polytechnic of Ambon, Indonesia \\ Elsina Huberta Aponno \\ Lecturer, Department of Business Administration, State Polytechnic of Ambon, Indonesia
}

DOI: $10.31364 / S C I R J / v 7 . i 9.2019 . P 0919693$

http://dx.doi.org/10.31364/SCIRJ/v7.i9.2019.P0919693

\begin{abstract}
The purpose of this study was to analyze the role of innovation as intervening variable or mediation on the entrepreneurial orientation and learning orientation towards the SMEs performance in Ambon city. The samples of this research were 299 units of SMEs in Ambon city. The data were analyzed through structural equation model (SEM) by the assistance of Amos 2.1 software. The result shows that entrepreneurial orientation has positive effect the company performance, learning orientation has positive effect the company performance, innovation mediated the impact of entrepreneurial orientation towards company performance, and innovation mediated the impact of learning orientation towards company performance on SMEs in Ambon city.
\end{abstract}

Index Terms - Entrepreneurial Orientation, Learning Orientation, Innovation, Company Performance

\section{BACKGROUND}

The current condition of the business world requires companies to take strategic steps towards the future after the economic crisis. Crisis conditions are characterized by conditions of high environmental uncertainty and turbulence (Govindarajan, 1984). The fact shows that despite having a number of advantages that allow small and medium enterprises (MSMEs) to survive in stopping the storm of crisis, not all small businesses can escape the adverse effects of the economic crisis (Handoyo, 2001). This is because MSMEs have a dynamic and uncertain business environment (such as competitors, customers, suppliers, regulators and business associations), as well as high competition intensity. It cannot be denied that this has become a trigger that has led to the emergence of performance and productivity inequality between MSMEs and large-scale businesses. The causes of weak performance and productivity of MSMEs are strongly suspected due to the weak character of entrepreneurship and the lack of optimal managerial role in managing business in a rapidly changing business environment as it is today (Hanifah, 2011).

In Indonesia, SMEs are the economic backbone. The number of SMEs in 2017 reached around 52 million. SMEs in Indonesia are very important for the economy because they contribute $60 \%$ of GDP and accommodate $97 \%$ of the workforce. But access to financial institutions is very limited, only $25 \%$ or 13 million SMEs have access to financial institutions. The Government of Indonesia, fostering SMEs through the Office of Cooperatives and SMEs, in each Province or District/City. In Maluku, the role of cooperatives and micro, small and medium enterprises (MSMEs) in moving the wheels of the economy continues to increase. The number of cooperatives in 2016 reached 2,965, in 2017 it increased to 3,023. While MSMEs from 22,513 units in 2016 increased 31,188 units in 2017. This achievement was the hard work of all parties, including the Cooperatives and MSMEs in all districts/cities in Maluku. This increase is not only seen in terms of growth. But continually the quality and competitiveness of cooperatives and MSMEs, both in terms of institutional and business in the era of globalization and the free market era, requires business actors and their products to be able to compete with products from outside.

Based on the map of Maluku Province's MSME distribution in 2013, it is seen that from the total number of MSMEs as much as 31,188, the city of Ambon is the region with the highest number of MSME distribution with a total of 7,348 businesses. Data on the number of small and medium-sized enterprise in the city of Ambon are shown in the following table :

Table 1. The Number of Small and Medium Sized Enterprise

\begin{tabular}{lrrrrrrr}
\hline \multicolumn{1}{c}{ Sub-District } & $\mathbf{2 0 1 1}$ & $\mathbf{2 0 1 2}$ & $\mathbf{2 0 1 3}$ & $\mathbf{2 0 1 4}$ & $\mathbf{2 0 1 5}$ & $\mathbf{2 0 1 6}$ & $\mathbf{2 0 1 7}$ \\
\hline Sirimau & 1.636 & 1.766 & 2.041 & 2.041 & 2.041 & 2.541 & 2.925 \\
Nusaniwe & 716 & 886 & 1.122 & 1.122 & 1.122 & 1.360 & 1.507 \\
T. A. Baguala & 415 & 460 & 945 & 945 & 1.115 & 1.393 & 1.543 \\
Teluk Ambon & 352 & 438 & 546 & 546 & 546 & 694 & 755 \\
Leitimur Selatan & 375 & 440 & 444 & 444 & 444 & 558 & 618 \\
\multicolumn{1}{c}{ Total } & 3.494 & 3.990 & 5.098 & 5.098 & 5268 & 6.546 & 7.348 \\
\hline
\end{tabular}


The table above shows the development of MSMEs in Ambon City from year to year. It shows that business opportunities in Ambon City are quite promising, thus encouraging people to open businesses in the fields of trade, industry and various services. By the growing development of MSMEs in Ambon City, the need for the development of entrepreneurial skills, the willingness of learning and innovation of the businesses being run are increasingly needed. Due to by this development, it will encourage an increase in better business performance. For this reason, business owners need to use various development strategies in order to develop their business.

Besides business strategy, the entrepreneurial orientation of the company plays a role in achieving success. Entrepreneurial orientation is known as a new approach to corporate performance updates. Entrepreneurial orientation is touted as a spearhead to realize sustainable and highly competitive economic growth of the company (Suryanita, 2006). Entrepreneurial-oriented companies will always strive to produce innovative new products and have the courage to face risks (Becherer and Maurer, 1997). Entrepreneurial orientation is seen as having the ability to improve the performance of a company.

Entrepreneurship is known as a new approach to corporate performance updates. This, of course, must be responded positively by companies that are starting to try to rise from the economic downturn due to a prolonged crisis. Building entrepreneurship is stated as one of the four pillars in strengthening employment. While entrepreneurship itself means a human activity by mobilizing mind power or body to create or achieve a work that can realize noble people. In other words, entrepreneurship means the main human being (superior) in producing a job for himself or others. People who do entrepreneurship are called entrepreneurs. The form of application for entrepreneurial attitudes can be indicated by an entrepreneurial orientation with indications of innovation, proactivity and risk taking ability.

In addition, innovation capabilities are related to new and unique business perceptions and activities. The ability to innovate is an important point of entrepreneurship and the essence of entrepreneurial characteristics. Some research results and entrepreneurial literature show that entrepreneurial orientation shows more significantly in companies that have the ability to innovate than those who do not have the ability to innovate. Innovation is a broader concept that addresses the application of new ideas, products or processes. Innovation is also defined as a successful application of the company's creative ideas. Therefore the company is expected to form new thoughts in dealing with existing competitors, customers and existing markets.

The similarity in the appearance of similar products and similar company systems from competitors is a driving factor for innovation, usually the competitor's product appears without experiencing changes which means it even tends to be static. This situation can be a profitable thing, because the competition that arises with the emergence of competing products can be overcome by product innovation. In addition to product innovation, systems within the company also need innovation. Innovation is something that can be seen as functional progress that can take it one step ahead of competitors, if it has an advantage that is seen as added value to consumers.

The development of new products and their strategies that are more effective often, determine the success and survival of a company, but this is not an easy job. New product development requires effort, time and ability including the magnitude of risk and the cost of failure. Cooper (2000) explains that the advantages of new products are very important in the circle of highly competitive global markets. These advantages cannot be separated from the development of innovative products that are produced, so that they will have an advantage in a market that will win in competition.

Continuous innovation in a company is a basic need which in turn will lead to the creation of competitive advantage. Conventionally, the term innovation can be interpreted as a breakthrough relating to new products. But along with the developments that occur, the notion of innovation also includes the application of new ideas or processes. Innovation is also seen as a company mechanism in adapting to its dynamic environment. Changes that occur in the business environment have forced companies to be able to create new thoughts, new ideas, and offer innovative products. Thus innovation increasingly has an important meaning not only as a tool to maintain the survival of the company but also to excel in competition.

A person's proactivity to achieve or produce good performance is another indication of the application of entrepreneurial orientation in person. Similarly, if a company emphasizes proactivity in its business activities, the company has carried out entrepreneurial activities that will automatically drive high performance. Companies with a high level of entrepreneurial activity mean they are seen from the high level of enthusiasm that never goes out because of obstacles, obstacles and challenges. Active and dynamic attitudes are the key words. The main function of high entrepreneurial orientation is how to involve measuring risk and risk taking optimally.

The attitude of entrepreneurship and the consequences of behavior to innovation are strongly influenced by the background of the leader which concerns the experience of the leader and the willingness to learn and increase self-capacity. Leadership ability will greatly influence the company's attitude in influencing the company's attitude in paying attention to market companies, being responsive to the company, market needs, often requires the design of new products to adjust to changes and exploitation of consumers, thus creating a competitive advantage of the company.

Companies with strong learning orientations continue to encourage, or even ask, employees to question organizational norms, values and practices that guide their actions and organizational activities. In this case, learning orientation influences the extent to which organizational members are encouraged, even challenged, to "think outside the box." Values that are routinely related to learning orientation range from (1) commitment to learning, (2) openness of mind, and (3) sharing vision.

SMEs that strive to improve the performance of their companies need to pay attention to three things, namely entrepreneurial orientation, learning orientation and innovation strategies. Entrepreneurial orientation and learning orientation are creative and innovative abilities that are used as a basis, tips and resources to find opportunities for success. While the innovation strategy is the way the company wins competition. These three things are seen as a foundation in creating better company performance. Given the importance of the role of entrepreneurial orientation, learning orientation and innovation strategies for SMEs, an adequate understanding of this is needed in order to improve the performance of SMEs. This study seeks to examine the relationship between entrepreneurial orientation, learning orientation and innovation on company performance. 


\section{LITERATURE REVIEW}

\subsection{Entrepreneurial Orientation}

Entrepreneurial orientation has become an important concept in the management and entrepreneurship strategy literature in the last twenty years. The study of performance reveals that an increase in the number of studies of entrepreneurial orientation has occurred throughout the world. Therefore it was concluded that "Entrepreneurship orientation is a promising area for developing relevant knowledge about entrepreneurship (Kusumawardhani, et. Al., 2009) and reflects the priority that companies are placed in the process of identifying and utilizing market opportunities (Baker \& Sinkula, 2009)"

Entrepreneurial orientation is recognized to have five dimensions based on the concept of Lumpkin and Dess (1996) which states that entrepreneurial orientation refers to organizational behavior at a certain level to do; 1) risk taking, 2) independent activities, 3) involved in innovation and 4) react proactively and 5) aggressively outperform competitors in the market (Campos, et. Al., 2011 and Kusumawardhani, et. Al., 2009). Thus, entrepreneurial orientation is a policy and practice that provides the basis for entrepreneurial decisions and actions. In other words, entrepreneurial orientation refers to how companies act in an entrepreneurial way (Kusumawardhani, et. Al., 2009). Many studies only use three dimensions (Parkman, et. Al. 2012, and Wang, 2008) which was originally developed by Miller (1983) to measure the extent to which a company's manager is 1) innovative, 2) proactive, and 3) dare to take risks in strategic decision making. Innovation reflects a tendency to support new ideas, novelty, experimentation, and creative processes. Proactive refers to the posture of an organization that anticipates and acts on future desires and needs on the market. Taking risks is associated with a willingness to use resources for projects whose results are unclear and failure costs may be high.

\subsection{Learning Orientation}

Learning orientation, as a source of competitive advantage and the key to future organizational success, has been subject to various disciplines including psychology, management, sociology and organizational theory, marketing, and strategic management Öhzşahin, et. Al., 2011). Learning orientation conceptualization, among others; broadly as the development of knowledge or insight that has the potential to influence behavior through values and beliefs in organizational culture (Hult. et. al., 2004), corporate values that influence the company's approach to obtaining information by emphasizing the importance of the planned process in enabling corporate learning to lead to the achievement of general organizational goals (Wang, 2008). By combining two approaches, learning orientation can be conceptualized as an encouragement of organizational values that influence the likelihood of a company to use and create knowledge (Öhzşahin, et. Al., 2011). Firms with strong learning orientations continue to encourage, or even ask, employees to question organizational norms, values and practices that guide their actions and organizational activities (Öhzşahin, et. Al., 2011).

Keskin (2006), Lin, et. al., (2008) describes a learning orientation component adapted from Calantone et al. (2002) where orientation learning refers to the activities of organizations to create and use knowledge to increase competitive advantage: 1) Commitment to learning; to what extent are the values of an organization that promotes a learning culture; 2) Dissemination of vision; organizational focus extends to learning, or the direction of learning; 3) Open mind; willingness to critically evaluate the organization's routine operations and to accept new ideas; and 4). Intraorganizational knowledge sharing; collective beliefs or behavioral routines related to the dissemination of the learning process between different units within the organization. Ma' atoofi, et. al., (2010), Eris, et. al., (2012), Baker \& Sinkulla (1999), Nasution, et. al., (2008) used the learning orientation dimension of Sinkula et. al., (1997) namely; commitment to learning, open mind, and dissemination of vision.

\subsection{Innovation}

Innovation is the name of the game for competition in the twenty-first century. Increased competition, unrelenting turbulence, change, and uncertainty have forced organizations to embrace innovation as an integral part of their corporate strategy (Keskin, 2006). Innovation enables organizations to progress along with changes in the environment because it is a strategic key in answering new challenges from an uncertain environment (Kocoglu Ipek, et. Al., 2011). A key component in the success of industrial companies is their level of innovation. Innovation is related to the company's capacity to be involved in innovation; that is, the introduction of new processes, products, or ideas in the organization. The capacity to innovate is one of the factors that has an important impact on business performance (Hult, et. Al., 2004).

There are many studies related to innovation. However, the researchers defined it from various perspectives. Lee, et. al., (2005) defines innovation as "ideas, products or processes, systems, or devices that are considered new to an individual, a group of people, or a company, industrial sector or society as a whole. Thus, innovation can occur in the domain of the product , processes and organizations. Kocoglu, et. al., (2011) defines innovation as: internal adoption resulting from devices, systems, policies, programs, processes, products, or services that are not necessarily new to the world but specifically new to the organization. Wu, et al., (2013) show that an innovation is defined as an idea, product or process, or system that is considered new to individuals.

Nybakk (2012) defines corporate innovation as the tendency of companies to create and / or adopt new products, manufacturing processes and business systems. Thus, the focus is on new products, processes and business systems for the company but not necessarily new to the market. Keskin (2006) adopted the view of Calantone et al. (2002) which defines corporate innovation as openness to new ideas as aspects of corporate culture by; 1) willingness to try new ideas, 2) look for new ways to do things, 3 ) be creative in operating methods and the level of product recognition. 


\subsection{Company Performance}

Performance is a theme that is constantly being studied in most branches of management, including strategic management by academics and practitioners. Although recipes for improving and managing organizational performance are widely available, academics are always preoccupied with discussions and debates on terminology, level of analysis, and conceptual basis for performance appraisal (Özşahin, et. al., 2011)

Two-dimensional classification scheme (Özşahin, et. al., 2011) is based on the concepts of Venkatraman and Ramanujam (1986). On the one hand, performance is distinguished from financial and operational indicators, and on the other hand, primary and secondary sources of information. Financial indicators relate to accounting measures and economic performance (eg earnings, sales), operational indicators related to operational success factors that can lead to performance such as customer satisfaction, quality, market share or new product development. From the perspective of information sources, primary data is collected from the organization while secondary data is collected from external or derivative databases.

The performance measures used in the survey may differ according to the objectives and characteristics of the survey. Subjective measures based on evaluations and judgments about company profitability, sales, market share, customer satisfaction and so on are often used in surveys related to management and organizational culture (Özşahin, et. al., 2011).

\section{HYPOTHESIS}

There are 4 developed hypothesis based on the description of the above concepts, especially regarding the direct influence of entrepreneurial orientation and learning orientation on performance and how those influences are through innovation as an intervening variable.

\subsection{Relationship of Entrepreneurial Orientation with Company Performance}

The relationship between entrepreneurial orientation and company performance has become the main focus of interest in learning entrepreneurial orientation (Kusumawardhani, et. al., 2009). A number of studies have shown that entrepreneurial orientation either directly or indirectly has a positive relationship with company performance (Wijesejara, et. al., 2014; Meutia, 2013; Pratono, et. al., 2013); Amin, 2015; Vasconcelos, et. al., 206; Nur, et al., 2014; Omar, et al., 2016, Setayanti, et. al., 2013) This means that companies that adopt a lot of entrepreneurial orientation are better at achieving performance compared to companies that are lack of learning orientation.

Research conducted by Amin, 2015 shows that entrepreneurial orientation has a significant relationship with the performance of SMEs in Saudi Arabia. This is in line with the findings of Vasconcelos, et. al., 2016, Omar, et. al., 2016, or Setyanti, et al., 2015 which states that directly entrepreneurial orientation affects business performance. Interestingly, there are also empirical findings that show that there is no relationship between entrepreneurial orientation and profit-generating ability which is one of the performance indicators (Baker and Sinkula, 2009). Based on the existing discussion, the hypothesis in this study are:

H1. Entrepreneurial orientation has a positive effect on company performance.

\subsection{Relationship between Learning Orientation and Company Performance}

Learning provides an opportunity for decisions that must be made with an understanding of various variables and relationships with processes and markets that set the stage for creating true customer value and choices that lead to desired business performance. Therefore, superior performance, in the long run, depends on the excellence of learning with a long-term systematic focus (Martinette and Lesson, 2012).

Empirical evidence shows a positive relationship between learning orientation and company performance. Previous findings concluded that learning orientation was positively and significantly associated with performance (Amin, 2015; Hassan, 2013; Jabeen, et. Al., 2013; Mahmood and Hanafi, 2013; Martinette and Lesson, 2012). Motsepe and Fatoki (2017) found a significant positive relationship between learning orientation and SME performance in Mpumalanga Province, in South Africa, in line with Serna, set al., (2016) which states that learning orientation is a good predictor for improving innovation and company performance. But there are also those who find that learning orientation does not have a significant relationship with performance (Vasconcelos, et. Al., 2016), in line with Pardi, et. al., (2014) which states that learning orientation does not significantly affect marketing performance. This discussion produces the following research hypothesis:

H2. Learning orientation has a positive effect on company performance

\subsection{Innovation as an intervening variable between Entrepreneurial Orientation and Performance}

As stated earlier, entrepreneurial orientation has a direct influence on performance, but it can also be influenced by other variables, one of which is innovation.

Empirical evidence that shows learning orientation is needed to achieve higher performance through corporate innovation (Nybakk, 2012), product innovation (Baker and Sinkula, 1999). This is in line with the findings of Zehir, et. al., 2015 which states that differences in innovation strategy and performance mediate the relationship between learning orientation and company performance; the effect of learning orientation on performance is partially mediated by innovation (Setyanti, et. al., 2013); through employee innovation as a moderator variable, learning orientation has a positive relationship with company performance. This discussion results the following research hypothesis:

H3. Innovation is an intervening variable between entrepreneurial orientation and company performance 


\subsection{Innovation as an intervening variable between Learning Orientation and Performance}

Innovation was also found to be a mediation between learning orientation and performance. An important point between learning orientation and innovation is that learning lays the foundation for innovation, because of the organization's dependence on improving the capacity of learning innovation, while at the same time affecting the overall performance of the company (Eris., Et. Al., 2012). Baker and Sinkula (1999) showed that learning orientation has a direct relationship with performance and also indirect relationships through product innovation. Eris, et. al. (2012) found innovation to act as a mediator in the influence of learning orientation on performance, in line with the findings of Nybakk (2012) and Lestari, et. al. (2018)

Although several studies have proven the mediating function of innovation between learning orientation and performance, research in this area is still not widely carried out. This is the basis for developing the following hypothesis:

H4. Innovation is an intervening variable between learning orientation and company performance

\section{RESEARCH METHODS}

This research was conducted in Ambon City which is the capital of Maluku Province with the highest number of MSMEs compared to other cities/districts. There are four variables used in this study, namely the variables of entrepreneurial orientation, learning orientation, innovation, and company performance. Based on the hypothesis and research model framework that describes the relationship between variables, then research instruments and samples are determined.

The population which is the unit of analysis in this study is the MSMEs registered in the Ambon City Office of Cooperatives and SMEs in 2017. According to Roscoe (1975) in Sekaran (2011); Hair, et al (2010); Tabachnick and Fidell (1996) obtained some general guidelines that can be used by researchers to determine the size. The research sample whose analysis using SEM requires a sample of at least 10 times the number of indicator variables used. This research has a total of 29 indicators, consisting of; Entrepreneurial Orientation 6 indicators, learning orientation 10 indicators, innovation 10 Indicators and firm performance 3 indicators. Therefore it requires a minimum sample of 10 x 29 or 290 samples. The sample used in this study amounted to 299 MSEs.

Sampling was carried out using purposive sampling technique that is random sampling according to the required sample requirements. The sample requirements in this study were MSMEs that were registered with the Ambon City Cooperatives and MSME Office in 2017. The main instrument in data collection in this study was to provide structured questions (questionnaires) adopted from various previous studies which were considered to have proven reliability and validity. The answers to the questions asked were changed on a Likert ordinal scale with the score range from 1-5, in which the value of 1 for very disagree / very small and the value of 5 for very agree / very large.

The collected data is processed using descriptive and quantitative analysis tools. The analysis technique to analyze data was SEM (Structural Equation Model) analysis using Amos software version 21.

\section{Structural Model Test}

\section{RESULT}

Structural model testing in this study was conducted to predict causality relationships between latent variables. Testing the structural model in this study basically wants to reveal the validity of the theoretical model built in this study through testing the research hypothesis (Hair et al, 2014 ).

Table 2. Goodness of Fit Measurement Test Result

\begin{tabular}{|c|c|c|c|c|}
\hline $\begin{array}{c}\text { Tipe goodness of } \\
\text { fit model }\end{array}$ & $\begin{array}{c}\text { Indeks goodness } \\
\text { of fit model }\end{array}$ & Cut of value & Hasil & Keterangan \\
\hline \multirow{2}{*}{$\begin{array}{c}\text { Absolute fit } \\
\text { measures }\end{array}$} & $\begin{array}{c}\text { Chi square } \\
\text { statistic }(\chi 2 \text { atau } \\
\text { CMIN) }\end{array}$ & $\begin{array}{c}\text { Expected to be } \\
\text { small }\end{array}$ & 477,093 & Less Fit \\
\cline { 2 - 5 } & $\begin{array}{c}\text { Normed } \chi 2 \\
\text { (CMIN/DF) }\end{array}$ & $\leq 2,00 / \leq 3,00$ & 1,450 & Fit \\
\cline { 2 - 5 } & GFI & $\geq 0,90$ & 0,897 & Fit \\
\cline { 2 - 5 } & RMSE & $\leq 0,08$ & 0,039 & Fit \\
\hline \multirow{2}{*}{$\begin{array}{c}\text { Incremental fit } \\
\text { measures }\end{array}$} & CFI & $>0,95$ & 0,956 & Fit \\
\hline $\begin{array}{c}\text { Parsimonius fit } \\
\text { measures }\end{array}$ & TLI & $>0,95$ & 0,956 & Marginal Fit \\
\cline { 2 - 5 }
\end{tabular}

Based on the results of testing the suitability of the model through absolute fit measures incremental fit measures and parsimonious fit measures which show that almost all models of the suitability index have good values except CMIN values that are not good, it can be concluded that this research model is categorized as good.

\section{Hypothesis Test}

The first hypothesis states that entrepreneurial orientation has a positive effect on company performance. The test results showed a significant Critical Ratio value $(\mathrm{CR}=2.027)$, a probability of $0.043(p<0.05)$ and a standardized estimation value of 0.177. Thus the results of this test indicate that the first hypothesis is supported. 
The second hypothesis states that learning orientation has a positive effect on company performance. The test results showed a significant Critical Ratio value $(\mathrm{CR}=2.134)$, a probability of $0.033(p<0.05)$ and a standardized estimation value of 0.150. Thus the results of this test indicate that the second hypothesis is supported.

The third hypothesis states that innovation is an intervening variable between entrepreneurial orientation and company performance. Mediation testing is done through the sobel test. The test results showed a significant level of $0.033(<0.05)$. Thus the results of this test indicate that the third hypothesis is supported.

The fourth hypothesis states that innovation is an intervening variable between learning orientation and company performance. Mediation testing is done through the sobel test. The test results showed a significant level of $0.050(<0.05)$. Thus the results of this test indicate that the fourth hypothesis is supported.

Table 3. Summary of Hypothesis Test Result

\begin{tabular}{|l|l|c|c|c|c|}
\hline \multicolumn{2}{|c|}{ Hypotesis } & $\begin{array}{c}\text { Standardize } \\
\text { d Estimation }\end{array}$ & $\begin{array}{c}\text { Critical } \\
\text { Ratio } \\
(\text { CR })=\mathbf{t}\end{array}$ & p-value & Conclusion \\
\hline H1 & $\begin{array}{l}\text { Entrepreneurial orientation had a } \\
\text { positive impact on company } \\
\text { performance }\end{array}$ & 0,177 & 2,027 & 0,043 & Accepted \\
\hline H2 & $\begin{array}{l}\text { Learning orientation had a positive } \\
\text { impact on company performance }\end{array}$ & 0,150 & 2,134 & 0,033 & Accepted \\
\hline H3 & $\begin{array}{l}\text { Innovation mediated the impact of } \\
\text { entrepreneurial orientation on } \\
\text { company performance }\end{array}$ & Sobel Test & 0,033 & Accepted \\
\hline H4 & $\begin{array}{l}\text { Innovation mediated the impact of } \\
\text { learning orientation on company } \\
\text { performance }\end{array}$ & Sobel Test & 0,050 & Accepted \\
\hline
\end{tabular}

Summary of hypothesis test result are presented in the following figure:

Figure 1.

Research model framework

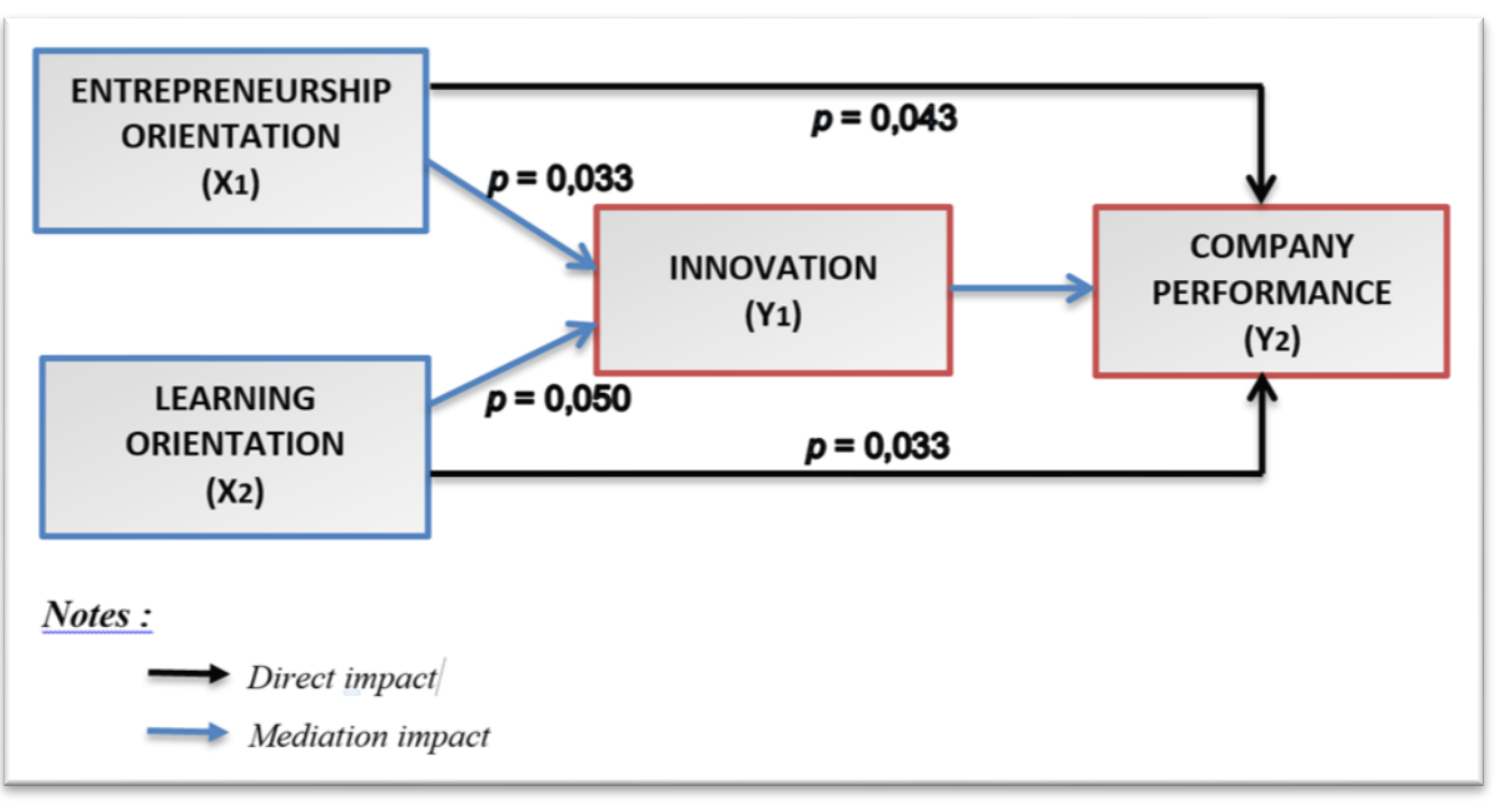

\section{DISCUSSION AND CONCLUSION}

The first hypothesis which states that the entrepreneurial orientation has positive effect on the company's performance is supported in this study. The conclusion of the results of this hypothesis test is the better entrepreneurial orientation, the better the performance of MSEs in Ambon city. The survey results showed that in general MSEs in Ambon city had a fairly good entrepreneurial orientation because the average answer score was 3.83. All dimensions of entrepreneurial orientation have also been implemented quite well by MSEs in Ambon City because the range of respondents' score scores is in the agreed value. Survey results show that MSEs in Ambon city are quite proactive, aggressive in competition and willing to take risks in running their business. The conclusion of the survey results on this hypothesis is that the better the attitude is proactive, aggressive, and willing to take risks the better the performance of MSEs in Ambon city. The results of this study are in line with Wijesejara, et. 
al., 2014; Meutia, 2013; Pratono, et. al., 2013; Amen, 2015; Vasconcelos, et. al., 2016; Nur, et al., 2014; Omar, et al., 2016, Setayanti, et. al., 2013. This research shows that the performance of MSEs can also be improved if the entrepreneurial orientation is improved. In more detail this can be done with an emphasis on research and development, technological leadership, making changes in products or services, initiating actions that must be responded to by competitors, daring to take big actions and having a strong tendency for high-risk projects. What can be done to improve entrepreneurship orientation at MSEs in Ambon city by referring to the results of the survey is to improve matters related to indicators with the lowest answer scores. MSEs in the city of Ambon must be more courageous and take the big actions needed to achieve the company's goals, must make changes to the product or service and must be able to cause competition or initiate actions that are responded to by competitors.

The second hypothesis which states that learning orientation has a positive effect on the company's performance is supported in this study. The conclusion from this hypothesis test is that the better the learning orientation, the better the performance of MSEs in Ambon city. The result of the survey shows that in general the MSEs in Ambon city had a fairly good learning orientation because the average answer score was 3.86. All dimensions of learning orientation have also been implemented quite well by MSEs in Ambon city because the range of respondents' score scores was in the agreed value. The results show that MSEs in Ambon city have enough commitment to study, a good enough shared vision and open mindedness. The conclusion of the survey results on this hypothesis is that the better the commitment to learn, a shared vision, and an open mindedness, the better the performance of MSEs in Ambon city. These results are consistent with Amin's findings , 2015; Hassan, 2013; Jabeen, et. al., 2013; Mahmood and Hanafi, 2013; Martinette and Lesson, 2012 ; Motsepe and Fatoki , 2017 ; Serna, et al., 2016. What can be done to improve the orientation of learning at MSEs in Ambon city by referring to the results of the survey is to improve matters related to indicators with the lowest answer scores. MSEs in the city of Ambon must have a mutual agreement on the vision of the organization at all levels, functions and divisions and all personnel must realize that the way they look at the market must continue to be questioned. In addition, MSEs in Ambon must also have the perception that employee learning is an investment, not a burden and must continue to assess the quality of decisions and activities taken from time to time.

The third hypothesis which states that innovation mediates the effect of entrepreneurial orientation on company performance is supported in this study. The conclusion of the results of this hypothesis test is that the better the entrepreneurial orientation the better the innovation and the better the innovation the better the performance of MSEs in Ambon city. The survey results show that in general MSEs in Ambon city have quite good innovations because the average answer score is 3.92 . All dimensions of innovation have also been implemented quite well by the UMK in Ambon city because the range of respondents' score scores was in the agreed value. The survey results show that MSEs in Ambon city have been quite good in product innovation, process innovation, and business system innovation. The conclusion of the survey results on this hypothesis is that the better the product innovation, process innovation, and business system innovation will increase the effect of entrepreneurial orientation on the performance of MSEs in Ambon city. The results of this study are in line with Baker and Sinkula ( 2009 ), after conducting three test models prove that the effect of entrepreneurial orientation on performance is mediated by innovation. Hafeez, et. al. (2012) in their literature study consider innovation often forgotten when examining learning orientation, resources, brands, and performance so that formulating a research preposition "Innovation mediates the relationship between learning orientation and company performance.

The fourth hypothesis which states that innovation mediates the effect of learning orientation on company performance is supported in this study. The conclusion of the results of this hypothesis test is the better the orientation of learning the better the innovation and the better the innovation the better the performance of MSEs in the city of Ambon. The conclusion of the survey results on this hypothesis is that the better the product innovation, process innovation, and business system innovation will increase the effect of entrepreneurial orientation on the performance of MSEs in Ambon city. The results of this study are in line with the findings of Baker and Sinkula (1999) which show that learning orientation has a direct relationship with performance but also an indirect relationship through product innovation. Eris, et. al. (2012) found innovation to act as a mediator in the influence of learning orientation on performance, in line with the findings of Nybakk (2012). The results of this study put innovation in a strategic position in an effort to mediate the effect of entrepreneurial orientation on the performance of MSEs in the city of Ambon. This effort can be done in a way; creating new business systems that are important for company success and actively developing in-house business system solutions and in-house production system solutions. In addition, MSEs in Ambon city must also actively develop and create new products that are important for the success of the company.

\section{IMPLICATION, LIMITATIONS, SUGGESTION FOR FUTURE RESEARCH}

In addition, the results of this study are also expected to provide guidance to the management of MSEs in Ambon on how entrepreneurial orientation and learning orientation can improve performance and how innovation can increase that influence.

In the future it is hoped that similar studies can be conducted with a wider variety of samples and wider locations so that research results can be generalized more.

\section{REFERENCES}

Amin Muslim, 2015. The Effect of Entrepreneurship Orientatiom and Learning Orientation on SME's Performance: an SEM-PLS Approach. Journal Intertional Business and Entrepreneurship Development, Vol. 8, No. 3, pp. 215-230.

Baker William E. \& Sinkula James M., 1999. Learning Orientation, Market Orientation, and Innovation: Integrating and Extending Models of Organizational Performance. Journal of Market Focused Management, Vol. 4, pp. 295-308. 
2009. The Complementary Effect of Market Orientation and Entrepreneurial Orientation on Profitability in Small Businesses. Journal of Small Business Management, Vol. 47, No. 4, pp. 443-464.

Becherer, Richard C. Dan John G. Maurer, 1997, “The Moderating Effect of Environmental Variables on the Entrepreneurial and Marketing Orientation of Entrepreneur-led Firms", Entrepreneurship Theory and Practice, Fall

Calantone Roger J., Cavusgil Tamer S., Zhao Yushan, 2002. Learning orientation, firm innovation capability, and firm performance. Industrial Marketing Management Vol. 31, pp. 515-524.

Campos Héctor Montiel, Parellada F. S., Valenzuela Lluis A. A., Mirabent J. B., Encalada J. A. D., 2011. The Impact of Moral Awareness on the Entrepreneurial Orientation Performamce Relationship in New Technology Based Firms. Journal of Technology Management \& Innovation Vol. 6, Issue 4, pp. 93-104.

Dinas Koperasi dan UKM Provinsi Maluku, 2013. Pandangan Umum. (http://www. kabartimur.co.id/index.php/daerah/item/475koperasi-umkm-maluku-meningkat). Diunggah tanggal 10 Juni 2014.

Eris Engin Deniz, Ozmen Omur N. T., 2012 The Effect of Market Orientation, Learning Orientation and Innovativeness od Firm Performances : A Research from Turkish Logistics Sector. International Journal of Economic Sciences and Applied Research, Vol. 5, No. 1, pp. 77-108.

Ghozali, Imam. 2006. Structural Equation Modeling. Metode Alternatif dengan Partial Least Square. UNDIP. Semarang.

Govindarajan, V. 1984. Appropriateness of Accounting Data in Performance Evaluation: An Empirical Examination of Environmental Uncertainty as An Intervening Variable. Accounting, Organizations and Society, vol. 9(2), pp. 125-135.

Hair, J. F. Jr., Black, W. C., Babin, B. J., dan Anderson, R. E., 2010. Multivariate Data Analysis, A Global Perspective, Seventh Edition. New Jersey ; Pearson Prentice Hall.

Handoyo A, 2001, "Pengaruh Orientasi Wirausaha Terhadap Kinerja Perusahaan Kecil dengan Lingkungan dan Strategi sebagai Variabel Moderat”, Thesis, Universitas Diponegoro, Semarang.

Hanifah, 2011, "Pengaruh Orientasi Kewirausahaan, Budaya Organisasi dan Strategi Bisnis terhadap Kinerja Perusahaan", Proseding Seminar Nasional Call for Paper, ISSN ISBN 978-979-3649-65-8

Hassan Masoodul, Mahmood Gohar, dan Nawas Muhammd Saqib, 2013. Inter Relationships Between Learning Orientation, Realationship Orientation and Business Performances: An Empirical Study on Pakistani Banking Sector. Middle-Fast Journal of Scientific Research, Vol. 16, No. 7, pp. 957-966.

Hult G. Tomas M., Hurley Robert F., Knight Gary A., 2004. Innovativeness: Its antecedents and impact on business performances. Industrial Marketing Management Vol. 33, pp. 429-438.

Jabeen Rubina, 2013. Antecedents of Firm's Performances. Empirical Evidence from Yemeni SME's. American Journal of Economics, Vol 3. No. 1, pp. 18-22.

Keskin Halit, 2006. Market orientation, learning orientation, and innovation capabilities in SMEs; An Extended Model. European Journal of innovation Management, Vol. 9, No. 1, pp. 396-417.

Kocoglu Ipek, Imamoglu Salih Zeki, Ince Hôseyin, 2011. The Relationship Between Organizational Learning and Firm Performance: The Mediating Roles of Innovation and TQM. Journal of Global Strategic Management, Vol. 09, pp. 72-88

Kusumawardhani Amie, McCarthy Grace, Parera Nelson, 2009. Framework of entrepreneurial orientation and networking: a Study of SMEs performance in a Developing Country. Proceedings of the Australian and New Zealand Academy of Management Conference, pp. 1-16.

Lee Tien-Shang dan Tsai Hsin-Ju., 2005. The effect of business operation mode on market orientation, learning orientation and innovativeness. Industrial Management \& Date System, Vol. 105, No. 3, pp. 325-348.

Lestari E. R., Ardianti F. L., and Rachmawati L., 2018. Firm Performance Model in Small and Medium Enterprises (SMEs) Based on Learning Orientation and Innovation. International Conference on Green Agro-industry and Bioeconomy.

Lin Chien-Huang, Peng Ching-Huai, Kao Danny T., 2008. The innovataiveness effect of market orientation and learning orientation on business performances. International Journal of Manpower, Vol. 29, No. 8, pp.752-772.

Lumpkin G. T., dan Dess Gregory G., 1996. Clarifying the entrepreneurial orientation construct and linking it to performance. The Academy of Management Review, Vo. 21, No. 1., pp. 135-172.

Ma'atoofi Ali Reza dan Tajeddini Kayhan, 2010. The Effect of Entrepreneurship Orientation on Learning Orientation and Innovation: A Study of Small-Sized Business Firm in Iran. International Journal of Trade, Economics and Finance, Vol. 1, No. 3, pp. 254-260.

Mahmodd Rosli dan Hanafi Norshafizah, 2013. Learning Orientation and Business Performances of Woman-Owned SME's in Malaysia: the Mediating Effect of Competitive Adavantage. British Journal of Arts and Social Sciences, Vol. 11, No.2, pp. 150-161. 
Martinette Louis A. Dan Leeson Alice Obenchain, 2012. The Relationship Between Learning Orientation And Business Performance And The Moderating Effect Of Competitive Adavantage: A Service Organization Perpective. Journal of Service Science, Vol. 5, No. 1, pp. 43-58.

Meutia, 2013. Entrepreneurial Social Competence and Entrepreneurial Orientation to Build SME's Business Network and Business Performance. International Journa; of Social and Humanity, Vol 3, No. 4, pp 381-385.

Motsepe E., and Fatoki O., 2017. The Realtionship between Learning Orientation and the Performance of Small and Medium Enterprises in South Africa. Journal of Economic and Behavioral Studies, Vol. 9., No. 3., pp. 232-240.

Nasution Hanny N., Mavondo F. T., Matanda M. J., Ndubisi N. O., 2011. Entrepreurship: Its realtion with market orientation and learning orientation and as antecedents to innovation and custumer value. Industrial Marketing Management, Vol. 40, pp. 336-345.

Nur Nofal, Surachman, Salim U., Djumahir, 2014. Entrepreneurship Orientation, Market Orientation, Business Strategy, Management CapabilitiesOn Business Performance; Study At Small And Medium Enterprise Printing in Kendari. International Journal of Business and Management Invention, Vol. 2, No. 12, pp. 8-17

Nybakk Erlend, 2012. Learning orientation, innovativeness and financial performance in traditional manufacturing firms : a higher-order structural equation model. International Journal of Innovation Management, Vo. 16, No. 5.

Omar N. A., Aris, H. Md., Nazri M. A., 2016. The Effect of Entrepreneurial Orientation, Innovation Capability and Knowledge Creation on Firm Performance; A Perspective on Small Scale Entrepreneurs. Jurnal Pengurusan, Vol. 48, pp.187-200.

Özşahin Mehtap, Zehir Cemal, dan Acar Zafer A., 2011. Linking leadership style to firm performances : the mediating effect of learning orientation. Procedia Social and Behavioral Science Vol. 24, pp. 1546-1559.

Pardi, Suharyono, Imam Suyadi, Zainul A., 2014. The Effect of Market Orientation and Entrepreneurnial Orientation toward Learning Orientation, Innovation, Competitive Advantages and Marketing Performance. European Journal of Business and Mnagement, Vol. 6, No. 21., pp. 69-80

Parkman Ian D., Holloway Samuel S., Sebastiao Helder, 2012. Creative Industies: Aligning Entrepreneurial Orientation and Innovation Capacity. Journal of Research in Marketing and Entrepreneurship, Vol 14, Iss. 1, pp. 95-114.

Pratono Aluisius Hery, Wee Tee Chee, Syahchari D. H., TyazNugraha A., Mat Nik K. N., and Fitri Haditi, 2013. The Direct Effect of Entrepreneurial Orientation and Innovation Success on Firm Performances. American Journal of Economics, Vol. 3(1), pp. 1-6.

Sekaran, U., 2011. Reasearch Methods For Business - Metodologi Penelitian Untuk Bisnis. Buku 2, Edisi 4. Jakarta : Salemba Empat

Serna M. D. C. M., Martinez J. E. V., and Martinez J. V., 2016. The Impact of Learning Orientation on Innovation and Performance in SME's in Mexico. International Review of Management and Busniess Research, Vol. 5., No. 1., pp. $48-64$.

Setyanti S. W. L. H., Troena E. A., Nimran U., and Rahayu, M., 2013. Innovation Role in Mediationg the Effect of Entrepreneurship Orientation, Management Capabilities and Knowledge Sharing Toward Business Performance: Study at Batik SMEs in East Java Indonesia. IOSR Journal of Busniess and Management, Vol. 4., No. 4, pp.16-27.

Suryanita A, 2006, "Analisis Pengaruh Orientasi Kewirausahaan dan Kompetensi Pengetahuan terhadap Kapabilitas untuk Meningkatkan Kinerja Pemasaran”, Thesis, Universitas Diponegoro, Semarang.

Vasconcelos N. S. A. V., Silveira A., and Bizarrias F. S., 2016. The Relation Between Entrepreneurial Orientation, Organizational Learning and Organizational Performance of Small Enterproses. International Journal of Professional Business Review, Vol. 1, No. 2, pp. 1-14.

Wang Catherine L., 2008. Entrepreneurial Orientation, Learning Orientation, and Firm Performance. Entrepreneurship Theory and Practice, Vol. 32, No. 4, pp. 635-656

Wijesejara W.A.D.S., Kumara P.A.P.S., Gunawardana T.S.L.W., 2014. Impact of Market Orientation and Entrepreneurial Orientation on Performance : A Study of Small and Medium Scale Garment Manufacturers in Sri Lanka. Proceeding of the 3rd International Conference on Management and Economic, pp 373-386.

Wu Chih-Wen, 2013. Global-Innovation Strategy Modeling of Biotechnology Industry. Journal of Business Research, Vol. 66, pp. 1994-1999. 